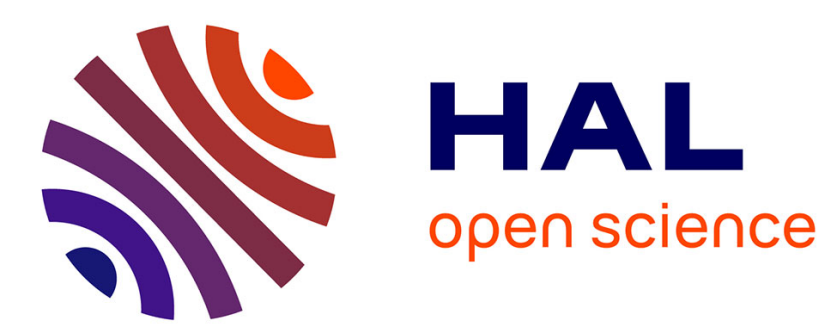

\title{
Competition and Cooperation in International Commercial Arbitration: The Birth of a Transnational Legal Profession
}

Florian Grisel

\section{- To cite this version:}

Florian Grisel. Competition and Cooperation in International Commercial Arbitration: The Birth of a Transnational Legal Profession. Law and Society Review, 2017, 51 (4), pp.790 - 824. 10.1111/lasr.12295 . hal-01666230

\section{HAL Id: hal-01666230 \\ https://hal.parisnanterre.fr/hal-01666230}

Submitted on 18 Dec 2017

HAL is a multi-disciplinary open access archive for the deposit and dissemination of scientific research documents, whether they are published or not. The documents may come from teaching and research institutions in France or abroad, or from public or private research centers.
L'archive ouverte pluridisciplinaire HAL, est destinée au dépôt et à la diffusion de documents scientifiques de niveau recherche, publiés ou non, émanant des établissements d'enseignement et de recherche français ou étrangers, des laboratoires publics ou privés. 


\title{
Competition and Cooperation in International Commercial Arbitration: The Birth of a Transnational Legal Profession
}

Florian Grisel

\begin{abstract}
This paper revisits the sociology of international commercial arbitration on the basis of unexploited archives and data. This material casts new light on the competition between "grand old men" and "young technocrats" in the 1980s and 1990s, a theme that has structured the analysis of international commercial arbitration since the pioneering work of Yves Dezalay and Bryant G. Garth (Dealing in Virtue). In contrast, the data show that the crucial transformative period actually took place between the 1950s and 1970s, when a relatively welldefined group of individuals emerged as the leading arbitrators at the International Chamber of Commerce. These individuals - the "secant marginals"succeeded in constructing a cooperative interface (rather than competition) between otherwise separate legal systems and professions. In doing so, they created the conditions necessary for the emergence of a new transnational legal profession. At a more general level, the article proposes an alternative narrative of globalization, wherein actors operating at the intersection of various systems, create new arenas of governance on the basis of inter-system cooperation.
\end{abstract}

For in the meantime the tightrope walker had begun his performance: he had come out of a small door and was walking along the rope, which was stretched between two towers so that it hung over the people and the marketplace. When he was just halfway across, the small door opened once again, and out jumped a colorful, buffoonish fellow who quickly followed after him. 'Move it, lamefoot,' he cried in a terrible voice, 'get going, lazybones, chiseler, whey-face! So I don't tickle your heel with my foot! What do you think you're doing here between these towers? Back in the tower is where you belong, behind bars, you who bar the way of one who is your better!'

Friedrich Nietzsche, Thus Spoke Zarathustra ${ }^{1}$

Please direct all correspondence to Florian Grisel, Centre national de la recherche Scientifique, Centre de Théorie et analyse du droit, 200 avenue de la République, Nanterre, France; email: floriangrisel@gmail.com

The author would like to express his deep thanks to the editors and anonymous reviewers of the Law E Society Review who have offered valuable feedback on this article. The author is also deeply grateful for the extremely helpful guidance provided by Robert C. Ellickson, Maria Hauser, Jan Paulsson, Alec Stone Sweet, Albert Jan van den Berg, V.V. Veeder, and Patrick Weil.

1 Transl. by Thomas Wayne, Part 1, Title 6. 
International commercial arbitration (ICA) has become the preferred method for the settlement of important transnational business disputes over the course of the last half century, ${ }^{2}$ displacing domestic courts (Stone Sweet and Grisel 2017). A network of arbitral institutions, the International Chamber of Commerce (ICC) being the most important, processes the bulk of these disputes, the stakes of which are enormous. A recent survey of the leading law firms in the field reported information on 109 active ICA cases in which at least $\$ 500$ million was "in controversy," including fiftyeight cases in which claims totaled more than $\$ 1$ billion, and nine with claims over $\$ 9$ billion. ${ }^{3}$ The actors who manage the system, typically leading arbitrators themselves, once worked in relative obscurity. Today, they publish scholarship, ${ }^{4}$ organize conferences, ${ }^{5}$ and build new organizational forms for promoting arbitration, ${ }^{6}$ activities that are now accessible to the public. As the importance of ICA has grown so has interest in the sociological profile of arbitrators, and in how they succeeded in constructing ICA as a private system of transnational governance.

The pioneering monograph by Yves Dezalay and Bryant G. Garth (1996), Dealing in Virtue, ${ }^{7}$ has dominated this topic for more than 20 years. Dezalay and Garth tracked the evolution of ICA between the 1980s and the 1990s, focusing on the competition between two groups of "merchants of law" which, they claimed, structured the emergence of a new "field" (Dezalay and Garth 1996: 57). The first group of incumbents was composed of "grand old men," a category dominated by "very senior European professors imbued with the traditional values of the European legal elites" (Dezalay and Garth 1996: 34). The second group of challengers was made of "young technocrats" who acquired their legitimacy as litigators in Anglo-American law firms (Dezalay and Garth 1996: 36). According to the authors, each of these groups drew their legitimacy from specific systems: the law schools of the civil law world on the one hand, and the law firms of the common

${ }^{2}$ On the disputing parties' preference for international commercial arbitration, see for instance the survey carried by White and Case and Queen Mary (University of London), "2015 International Arbitration Survey: Improvements and Innovations in International Arbitration."

3 Michael Goldhaber (2013) “Arbitration Scorecard 2013: Contract Disputes," The American Lawyer 1 July.

4 Specialized reviews count, among others, Arbitration International, the Journal of International Arbitration, and the Revue de l'arbitrage.

5 The annual congress organized by the International Council for Commercial Arbitration (ICCA) is particularly important in the field.

6 These include, for instance, the ICCA and the Milan Club of Arbitrators.

7 This book followed an article published in the Law E Society Review (Dezalay and Garth 1995). 
law world on the other hand (Dezalay and Garth 1996: 33-62). The divides between these two groups - cultural (civil law/common law), generational (old/young), and professional (professors/attorneys) - were progressively resolved in favor of the young technocrats. They prevailed over the grand old men in the 1980s, pushing arbitration from (1) an informal mode of dispute settlement to (2) a judicialized system more akin to U.S. "litigation" (Dezalay and Garth 1996: 54). Put summarily, the "victory" of the young technocrats led to the emergence, and steady Americanization, of a new version of ICA.

Scholars subsequently grounded new research on the arguments of Dezalay and Garth. Franck, for example, mentioned a "shift in the group serving as arbitrators, which has grown beyond the 'grand old men' to a younger generation of arbitration technocrats" to introduce her study of the "role" of international arbitrators (Franck 2006: 500). Others have sought to update the conclusions of Dezalay and Garth in light of additional data. Schultz and Kovacs claim, on the basis of a survey of lawyers and arbitrators, that a "third generation of arbitrators" (the "Managers") has now emerged (Schultz and Kovacs 2012). Arbitrators themselves have adopted terms employed by Dezalay and Garth, referring to what they do as "practicing virtue" (Caron et al. 2015). More generally, the prioritization of a small group of "lawyers that count" (Dezalay et al. 2015: 27) ${ }^{8}$ has had a strong influence on the ways in which sociolegal scholars have analyzed the significance of legal elites in globalization processes (Dezalay and Madsen 2012; Hagan et al. 2006; Kauppi and Madsen 2013; Sacriste and Vauchez 2007; Shaffer et al. 2015).

Dealing in Virtue has not only been highly influential, it has also gone largely unchallenged. Dezalay and Garth based their analysis on "almost three hundred interviews" (Dezalay and Garth 1996: 9), making any challenge a daunting task. ${ }^{9}$ This paper is based on the analysis of new data that was specifically compiled to explore an alternative explanation. Dezalay and Garth emphasized incompatibilities between systems, tensions that produced what they portray as a zero-sum competition

8 See Puig (2014) for an application to investor-state arbitration.

9 One early critique should be noted in this regard. A book reviewer of Dealing in Virtue, who happened to be a former Secretary-General of the ICC International Court of Arbitration, argued that "there [wa]s little basis, in [his] view, for the authors' contention that conflict between an aging cadre of notables, i.e., 'grand old men,' and a younger generation of 'technocrats' has helped to shape the modern development of international commercial arbitration" (Schwartz 1997: 231). Among other reasons, Schwartz pointed out how "many of those prominent in international arbitration are at the same time academics and practitioners, which makes it even more difficult to speak of cleavage between the two." (Schwartz 1997: 232). 
between two types of practitioners, which the common law technocrats won, and the grand old men of the civil law lost, in the 1980s and 1990s. The basic structure of Dezalay and Garth's argument is as follows: (1) ICA was dominated by professorial "grand old men" prior to the 1980s; (2) "young technocrats," trained in a litigious culture of the common law, became the prevailing elite of ICA thereafter; and (3) this change in power drove the judicialization of ICA, that is, toward a full-fledged transnational substitute for national courts. This paper challenges each of these elements. The analysis indicates that the crucial period of institutional transformation took place between the 1950s and 1970s, when ICA became dominated by "secant marginals" operating at the intersection of the legal systems and professions. The term, "secant marginals," refers to those individuals who, while being members of multiple social groups (national, ethnic, professional), do not develop a sense of primary identity, or exclusive loyalty, with regard to any one of these groups. As a result, they are better able to develop the types of knowledge-based power and legitimacy that enable them to become skilled brokers at the intersection between systems (Crozier and Friedberg 1977: 86).

In order to identify, and track the influence of, these agents, I compiled data on the composition of elites in ICA at different stages of historical development, before and after the time frame of Dezalay and Garth's empirical research. The data show that the "secant marginals," operating between 1950 and the 1970s, largely determined the modern evolution of ICA. They did so by building a hybrid system, made up of bridges that connected different legal systems and professions in the service of a common purpose: to reconstruct ICA by judicializing it. These actors engaged in intensive institutional "bricolage" (Lévi-Strauss 1962), combining elements from different systems in order to create a system at once new and familiar. The central importance of the "secant marginals" in the construction of ICA is further confirmed by the fact that members of the current ICA elite-far from being "young technocrats" à la Dezalay and Garth-reproduced the features of their peers in the 1950s and 1960s. The findings are consistent with empirical studies that have highlighted the "interdiscursive" structure of ICA, characterized by the blending of professional (and legal) practices (Bhatia 2011: 80; Bhatia et al. 2012). The empirics also provides further insights into the sources of a distinct, transnational "culture" for ICA which, Karton has argued, is today based on "a coherent set of norms outside of any national culture, in [a] discrete, international space" (Karton 2013: 10). 
Beyond the analysis of ICA lies another broader debate on the processes through which globalization has proceeded after the Second World War. Dezalay and Garth proposed a narrative of legal globalization "constructed by agents operating from clearly defined national home bases, a process which has implications both for the dynamics of the national as well as the emergent international legal field" (Buchanan 1997: 365). In other words, the competition among approaches based on distinct legal traditions would eventually produce a set of dominant standards and practices which would, in turn, form the basis of a new globalized legal field. This narrative, which has been described as "the most consistently conceptualized and far-reaching examination[s] of the globalization of law to date" (Munger 2012: 476), privileges focus on the competition between various national approaches and actors (Halliday 2012: 267; Legrand 2006: 527; Merry 2006: $3)$. I argue here that the construction of sites of global governance may also depend critically on those actors whose efficacy flows from their positions as skilled actors along systemic borders. This counter-narrative emphasizes the importance of a stable, transnational interface between systems, rather than the triumph of one logic of social power and legitimacy over another. ${ }^{10}$ With regard to the transformation of ICA, distinct systems did not matter as much as the instantiation of the new transnational space in which they intersect. Local elites usually do not fare well in the construction of such (once virtual, now real) spaces, precisely because loyalties are too obviously grounded in more parochial systems.

\section{Preliminary Observations}

This paper argues that Dezalay and Garth over-emphasized conflict and competition, while failing to consider adequately the significance of the development of new modes of cooperation in the transformation of ICA. In particular, they fail to consider the extent to which new entrants into ICA self-consciously forged a new transnational hybrid from elements found in multiple legal traditions. There are two sources of this problem: (1) the influence of the Bourdieusian analytical frame on Dezalay and Garth's analysis, and (2) the limitations of analyzing data collected almost exclusively through interviews.

10 A distinction could be drawn in this regard between the "international," which has been constructed by States, and the "transnational," which involves a wider range of actors and institutions (Jessup 1956: 3). 


\section{The Bourdieusian Tradition}

Dezalay and Garth situate themselves within the strictures of a tradition founded by Bourdieu (Dezalay et al. 2015: 20). ${ }^{11}$ In his foreword to Dealing in Virtue, Bourdieu emphasized the importance of conflicts between national traditions in the creation of a transnational legal field:

[...] conflicts between jurists of different countries seeking to impose their judicial forms, or their modes of producing law, contribute to the progressive (and unfinished) unification of the global legal field and the global market of legal expertise. The international is constructed largely from the competition among national approaches. [...] This process makes the international the site of a regulatory competition between essentially national approaches. (Dezalay and Garth 1996: vii-viii).

Although Bourdieu did not apply his analytical frame to the analysis of the law (see, however, Bourdieu 1986; Bourdieu 2012: 487-587; see also Dezalay and Madsen 2012; Lenoir 2004b: 23153 ), his approach generally reflected this view of the dynamics of social change, whether applied to French schools (Bourdieu 1989), academic discourse (Bourdieu 1984), or governmental regulatory systems (Bourdieu 2012: 275-346). Bourdieu's analytical frame, which focuses on the battle between the "dominant" and the "dominated" as an engine of social evolution (Pinto 2002: 53 ), has its roots in the Marxist analysis of class struggle (Lenoir 2004a: $146-48){ }^{12}$

This bias in favor of conflict, more theory-driven than empirical, downplays the importance of cooperation to social change that have been explicated by other theorists (Axelrod 1990; Dixit 2004: 65-76). Since Dealing in Virtue appeared, institutional and economic sociology has experienced a broad revival leading to, among other things, a reconceptualization of the notion of the field and of the dynamics of field construction and maintenance. Most contemporary research begins from the standpoint that "both competition and cooperation are fundamental to field analysis" (Fligstein and McAdam 2012: 24-26), and that "[f]ield stability is generally achieved in one of two ways: through the imposition of hierarchical power by a single dominant group or the

11 Pierre Bourdieu was Yves Dezalay's PhD supervisor (Dezalay 1992). Dezalay and Garth emphasized that they used Bourdieu's "structural approach" as a "starting point" (Dezalay and Garth 1996: 4).

12 It should, however, be noted that Bourdieu distanced himself from the Marxist analysis, see Bourdieu (with Wacquand) 1992: 219-21. 
creation of some kind of political coalition based on the cooperation of a number of groups" (Fligstein and McAdam 2012: 14). This paper assesses the importance of factors associated with both. ${ }^{13}$ The objective is not to deny the importance of competition as an agent of social change but rather to simply illustrate how social strategies may borrow, in subtle ways, from cooperation and competition in processes that are often intertwined. This approach shifts the focus from competition to cooperation in a move that is equally informed by the self-interested maximization of the agents' position within the field (Buchanan 1997: 370). In particular, the article will show how professional groups that were deemed to be in competition have, in fact, blended into a unified, hybrid, legal profession at the transnational level. It will also show how the individuals working at the intersection of these various groups-the "secant marginals"succeeded in constructing a cooperative (rather than uniquely competitive) interface between otherwise separate legal systems and professions, and had already begun to judicialize ICA in the 1950s. This process has unfolded on a larger temporal scale and in ways that have been, in my view, misinterpreted.

\section{Self-Representations in International Commercial Arbitration}

Dezalay and Garth's conclusions are based on interviews with practitioners of ICA carried over a three-year period in the 1990s (Dezalay and Garth 1996: 9). Although Dezalay and Garth purport to capture the evolution of ICA over a 20-year period, between the 1980s and the 1990s (Dezalay and Garth 1996: 61), they do not explore what took place prior to these decades. This paper argues that the crucial transformative period took place before the 1980s, and the data and qualitative research provide strong support for this contention.

In addition, the exclusive recourse to interviews raises methodological issues in a domain, such as ICA, where the group of practitioners is portrayed as a closed "club" to which outsiders are eager to accede (Dezalay and Garth 1996: 10). In this context, challengers have an interest in differentiating themselves from members of the dominant group and over-emphasizing their differences with this group. Conversely, the incumbent group may have an interest in falsely portraying the challengers in order to preserve their dominant position; self-representations may lead to strategic misrepresentations. In a recent interview, one of the authors noted that the "young technocrats" were not only more

13 Karton noted how Dezalay and Garth's deductive approach, based on "a priori sociological models such as Bourdieu's," might have caused a distortion of reality (Karton 2013: 38). 
eager to participate in the interviewing process than the grand old men but that they also sought to artificially emphasize their differences from the "grand old men" and even "manipulate" the interviewing process (Dezalay et al. 2015: 21-22). He further argued that the limited size of the object of inquiry (ICA) and its "fluidity" made it difficult to have recourse to quantitative methods (Dezalay et al. 2015: 26). The present article seeks to re-balance the "objectivist" and "subjectivist" approaches by introducing quantitative data (based on archival research) associated with qualitative analysis (based on individual profiling).

These preliminary observations suggest that: (1) a study of the evolution of ICA arbitration should be temporally broader than twenty years in order to faithfully account for long-term evolution; (2) data collection should include direct evidence of sociological change (and not focus solely on indirect evidence); and (3) the analysis should consider the importance of factors and interactions related to both conflict and cooperation. ${ }^{14}$

\section{Presentation of the Data}

One of the key difficulties of the research on ICA arises from the confidentiality of arbitral proceedings and the difficulty in accessing evidence pertaining to the long-term evolution of the field (Bhatia 2010: 469-79). The present article relies on two datasets in order to provide a more fine-grained sociological picture of ICA over a long-term period. Analysis of these data enables the assessment of events that unfolded prior to the 1980s, and to assess their effects afterward. The first dataset provides strong support for the view that the leading figures at the ICC, operating prior to 1972, acted at the intersection of various social groups, as "secant marginals" in the transformation of ICA. Analysis of the second dataset shows that the leading arbitrators identified by Dezalay and Garth as the young technocrats actually reproduced the sociological features of these "secant marginals."

I compiled the first dataset through archival research at the ICC, the leading institution in ICA, and the main case study of Dezalay and Garth (1996: 13). The ICC has administered proceedings since the creation of its "Court of Arbitration" in the early 1920s. The ICC Court of Arbitration ${ }^{15}$ appoints arbitrators, chooses

14 It is noteworthy in this regard that in a recent paper, Dezalay and Garth broadened the temporal horizon of their study and stressed-on the basis of archival research-the possible "alliances" between "fractions of national elites whose interests converge or whose resources are complementary" (forthcoming).

15 The Court of Arbitration was renamed the International Court of Arbitration in 1998. 
cities in which arbitration proceedings are seated, and scrutinizes draft awards. It has, over nearly a century, been the leading institution in ICA. Dezalay and Garth described the ICC as a "central institution" and the "most universal of the arbitration institutions" (1996: 45). Today, it is still the most global institution, when considered in terms of the national diversity of parties and arbitrators (Stone Sweet and Grisel 2017: 45-46). ${ }^{16}$ I gathered information on more than a thousand appointments of arbitrators, in 644 ICC cases resolved between 1922 and 1973, on which archival data were available. ${ }^{17}$ Cases after 1973 were not made available for confidentiality reasons. I coded for arbitrators, gender, nationality, date of birth, profession, and whether they were nominated for the first time. This dataset provides key information on ICC arbitrators immediately prior to the time period studied by Dezalay and Garth.

The second dataset extends the empirical research, both temporally and materially, and places the first dataset into broader perspective. Most important, it allows us to identify the social strategies that would eventually prevail among ICA elites, putting the conclusions drawn from the first dataset to the test of time. This dataset is based on the Who's Who List of the Most-Highly Regarded Individuals in Commercial Arbitration (2015). ${ }^{18}$ This list was established on the basis of a yearly survey of the individuals who were ranked most highly by arbitration users and actors in 2015. As such, it provides a picture of the most successful and recognized individuals in ICA today. For each of these 25 individuals, I gathered information pertaining to their genders, nationalities, and dates of birth. I also determined whether they were attorneys or barristers, whether they had any significant academic activity, ${ }^{19}$ and whether they had any significant affiliation with a leading arbitral institution. ${ }^{20}$ This information concerns ICA elites beyond the time period analyzed by Dezalay and Garth.

16 It is acknowledged that the sociological profile of arbitrators in other leading arbitral institutions (for instance, the London Court of International Arbitration or the Stockholm Chamber of Commerce) may differ from the present data.

17 These cases were resolved either by decision of the arbitrators or by settlement between the disputing parties.

18 This list is available at: http://whoswholegal.com/news/analysis/article/32630/arbitration-2016-analysis/ (accessed 17 August 2016).

19 I considered several factors to establish the existence of a "significant academic activity," including the number of scientific publications in specialized reviews, any affiliation with universities or law schools, and memberships in scientific societies.

20 I considered only individuals who held an official position in one of the leading arbitral institutions (International Chamber of Commerce, London Court of International Arbitration, Stockholm Chamber of Commerce, American Arbitration Association, Dubai International Arbitration Centre, Singapore International Arbitration Centre, Hong Kong International Arbitration Center, and China International Economic and Trade Arbitration Commission). 
Table 1. The Grand Old Men, 20 Years Before (1922-1973)

\begin{tabular}{lllclc}
\hline Name & Gender & Nationality & $\begin{array}{c}\text { Year of } \\
\text { Birth }\end{array}$ & Profession & $\begin{array}{c}\text { Number of } \\
\text { Appointments }\end{array}$ \\
\hline Ernest Barda & M & Italian & 1903 & Attorney & 13 \\
Ottoarndt Glossner & M & German & 1923 & Attorney & 11 \\
Berthold Goldman & M & French & 1913 & Professor & 13 \\
Lazare Kopelmanas & M & French & 1907 & International civil & 13 \\
Gunnar Lagergren & M & Swedish & 1912 & Judge & 13 \\
Ernst Mezger & M & German & 1909 & Attorney & 10 \\
Henri Monneray & M & French & 1914 & Attorney & 12 \\
André Panchaud & M & Swiss & 1901 & Judge & 13 \\
Pierre-Jean Pointet & M & Swiss & 1910 & Professor & 16 \\
Paul van Reepinghen & M & Belgian & 1912 & Trade federation & 28
\end{tabular}

\section{Analysis of the Data and Discussion}

\section{"Grand Old Men" Versus "Secant Marginals"?}

The first dataset provides an exhaustive picture of the individuals who were nominated as arbitrators in ICC cases from 1922 to 1973 . To identify the most prominent members of this community, I selected the names of arbitrators who obtained more than 10 appointments during this time period. The list of these names, which is given in Table 1 , provides a picture of the "grand old men" approximately 20 years before Dealing in Virtue. Altogether, these "grand old men" gathered 142 appointments, more than 10 percent of the total number of arbitrators' appointments between 1922 and 1973. Their average age was 61.2 years old, with a standard deviation of 4 years (in $1973^{21}$ ). None of the individuals who had obtained 10 or more appointments acted as arbitrators prior to 1945 .

A review of the individual profiles provides relevant insights on the backgrounds of the "grand old men." Most were not established elites of a national legal system, or national professional association, and were highly unlikely to promote "their" own vernacular approaches. On the contrary, they appeared to be travelers, often migrants, who cultivated professional eclecticism across borders. These arbitrators fit the profile of "secant marginals" (Crozier and Friedberg 1977: 86), whose legitimacy is rather weak in specific systems but who are able to mediate in the interstices between systems. They are also symmetrically opposed to the Bourdieusian "grand old men" who solidly belong to one of these systems, do not wish to extract themselves therefrom, and aggressively sing the praises of their system(s) externally (Crozier and Friedberg 1977: 220). These "marginals" compare well with the "first-order intermediaries" who mediated

21 Ernest Barda died in 1966. 
the "global/local encounter" in bankruptcy law (Carruthers and Halliday 2006: 529-32). They can also be likened with the intermediaries who translated local grievances in the parlance of global human rights in Hong Kong (Merry 2006: 193-94, 21012). However, contrary to these intermediaries, the leading arbitrators at the ICC held significant power in their own constructed space but rarely in the local spaces from which they drew aspects of their legitimacy. While they were particularly effective when circulating within their own transnational space, they were less so when crossing local spaces (although they were sufficiently equipped to mediate between these spaces).

The role of "secant marginals" in the construction of a transnational space is not specific to ICA. In fact, other transnational spaces have been constructed in similar ways. For instance, Tarrius showed that migratory flows and associated economic activity benefited from the intervention of "unofficial notaries," whose mediation between local authorities, ethnic groups, and semicriminal networks created the possibility for transnational governance of migration to emerge in southern Europe (Tarrius 2008: 176-78). "Unofficial notaries," as with leading arbitrators at the ICC, played a mediating role by nurturing various associations with distinct groups while limiting their loyalty to any of them. I will further illustrate the argument by analyzing individual trajectories of these arbitrators.

\section{Travelers and Migrants}

Many of the people in Table 1 were travelers and migrants who carried multiple legal identities and cultures. Ernest Barda was an Italian attorney who was born in Egypt and studied and practiced law in France. He wrote his doctoral dissertation under the supervision of Professor Lévy-Ullmann on "Specific performance or performance 'in specie' in the contracts of comparative English law" and was an active member of the Société de législation comparée $^{22}$ from 1928 until his death in $1966 .{ }^{23}$ Ernst Mezger was an attorney who left Germany for France after the Nazi rise to power because of his Jewish origins. Heinrich Meierhof (who changed his name to Henri Monneray) fled Germany in 1933 for the same reasons before studying law in Paris, becoming a deputy

22 The Société de Législation Comparée is a scientific society based in Paris devoted to the study of comparative law and foreign law. It has consultative status with the Economic and Social Council of the United Nations, the International Labour Office and the Council of Europe, see http://www.legiscompare.fr/web/Presentation-de- la-SLC (accessed 18 August 2016).

23 See Marc Ancel (1967) “Ernest Barda," 19/3 Revue Internationale de Droit Comparé 702. 
prosecutor at the Nuremberg trials and an attorney in Paris after the Second World War. ${ }^{24}$ In the late 1940s, he published two volumes of documents (based on materials used in Nuremberg) on the persecutions of Jews throughout Europe during the Second World War. ${ }^{25} \mathrm{He}$ was an expert for France in a case brought before the International Court of Justice in the late $1950 \mathrm{~s} .{ }^{26}$ Berthold Goldman was a French professor who was born in Bucharest in 1913, left Romania for France in 1930, became a law professor (with a first academic position held in "Indochina") and ended up presiding over the University of Paris II from 1974 until 1979. ${ }^{27}$ Lazare Kopelmanas was born in Lithuania in 1907, studied law in Switzerland and France, taught in France, the United States, the Netherlands, and Switzerland, and worked as an international civil servant at the United Nations Office in Geneva. ${ }^{28}$ Although Paul van Reepinghen spent most of his career in Belgium, his activity as an international arbitrator earned him the Order of Merit of the Italian Republic. ${ }^{29}$ The same is true of Ottoarndt Glossner, who spent most of his career in Germany, while studying law in Germany, France, and the United Kingdom and obtaining the French Legion of Honor in $1993 .^{30}$

These individuals did not draw their authority from their national positions, contrary to the claim that they had "risen to the top of their national legal professions and gained financial independence before asked to serve as arbitrators" (Dezalay and Garth 1996: 35). In fact, some of them were rather unknown in their respective countries, and their local careers occasionally suffered as a result of their migrations and travels. Ernest Barda, Ernst Mezger, and Henri Monneray (all immigrants) were leading arbitrators at the ICC, but they failed to achieve distinction as local attorneys. Similarly, Lazare Kopelmanas, Pierre-Jean

24 See Laura Jockusch (2007) “"Collect and Record! Help to Write the History of the Latest Destruction!' Jewish Historical Commissions in Europe, 1943-1953.” Ph.D. dissertation, Department of Hebrew and Judaic Studies, New York University, 479.

25 See Henri Monneray (1947) La Persécution des Juifs en France et dans les Autres Pays de l'Ouest. Paris: Ed. du Centre; Henri Monneray (1949) La Persécution des Juifs dans les Pays de l'Est. Paris: Ed. du Centre.

26 See Case of Certain Norwegian Loans, Judgment of July 6th, 1957: I.C.J. Reports 1957 , p. 9 , p. 6 .

27 See Jean-Denis Bredin (2004), "Berthold Goldman, Toujours Vivant," in Fouchard P., et al., eds., L'actualité de la Pensée de Berthold Goldman. Paris: Editions Panthéon-Assas, 1518.

28 See Lazare Kopelmanas (1976), "L’application du Droit National Aux Sociétés Multinationales," in Collected Courses of the Hague Academy of International Law, Vol. 150. Leiden/ Boston: Brill/Nijhoff. 298.

29 E-mail from Mr. Laurent van Reepinghen dated 13 July 2016.

30 Alain Plantey et al., eds. (1994) Festschrift für Ottoarndt Glossner zum 70. Geburtstag. Heidelberg: Verlag Recht und Wirtschaft. 6. 
Pointet, and Paul van Reepinghen were not very influential in their respective countries. Of course, all these arbitrators carried some form of social influence, but they were not the power brokers of the kind described as the "grand old men." Even Berthold Goldman, who showed all the signs of social prestige in France (and was described as a prime example of "grand old man" by Dezalay and Garth [1996: 53]), was hit by a wave of anti-Semitism and racism (as a naturalized French who was Jewish and born in Romania) in response to his appointment as president of the University of Paris II in $1974 .{ }^{31}$ Compare the national profile of these arbitrators with that of international judges. The judges at the International Court of Justice (ICJ) typically display high levels of social capital in their respective countries, ${ }^{32}$ in contrast to the individuals listed in Table 1 .

Some of the latter displayed more traditional profiles grounded in national legal traditions, but these were more the exception than the rule. Two individuals in Table 1, who were both judges in their countries of origin (Sweden and Switzerland), match that profile. The first, André Panchaud, was a judge at the Swiss Federal Tribunal from 1948 until 1970, over which he presided in 1967 and $1968 .{ }^{33}$ The second, Gunnar Lagergren, was a Swedish judge who presided over the Court of Appeal for Western Sweden between 1966 and 1977, before heading the administration of the Royal Court of Sweden (Marshal of the Realm) until $1982 .{ }^{34}$ Lagergren subsequently became a judge at the European Court of Human Rights (1977-1988) and the first president of the Iran-U.S. Claims Tribunal (1981-1984). ${ }^{35}$ Lagergren was associated by marriage with one of the most influential families in Sweden (the Wallenberg family). ${ }^{36}$ He became the first chairman of the Raoul Wallenberg Institute for Human

31 See Jean-Denis Bredin (2004), "Berthold Goldman, Toujours Vivant," in Fouchard P., et al., eds., L'actualité de la Pensée de Berthold Goldman. Paris: Editions Panthéon-Assas. 1518.

32 For instance, the judges appointed by France at the ICJ were all high-level public officials in this country (three out of five were members of the Conseil d'Etat, the Supreme Administrative Court; and the remaining two came from the Ministry of Foreign Affairs). Similarly, the judges appointed by the United Kingdom were all prominent professors, barristers or members of the Foreign Service (four out of seven held the prestigious Whewell Professorship at Cambridge University or the Chichele Professorship at Oxford University).

33 See Lucienne Hubler (2009) "André Panchaud" in Dictionnaire Historique de la Suisse. Available at: http://www.hls-dhs-dss.ch/textes/f/F16254.php (accessed 10 April 2017).

34 See Gunnar Lagergren \& George H. Aldrich (2002) “An Old Judge Remembers,” 14 Leiden J. of International Law 307.

35 Ibid.

36 Ibid. (His wife, Nina von Dardel, was Raoul Wallenberg's step-sister.) 
Rights and Humanitarian Law. ${ }^{37}$ In addition, the Wallenberg family has had a longstanding involvement with the ICC (Dezalay and Garth 1996: 188). Knut A. Wallenberg-a former Swedish Foreign Minister-was involved in the creation of the ICC in the early $1920 \mathrm{~s},{ }^{38}$ and subsequently became one of its vice-presidents. ${ }^{39}$ His nephew, Marcus Wallenberg, Jr., served as an alternate member of the ICC Council in the $1930 \mathrm{~s}^{40}$ The connection between Lagergren and the ICC through the Wallenberg family might explain his ease at gathering appointments as an arbitrator. Indeed, Lagergren himself reported his repeated connections with the ICC:

The ICC had its headquarters in Paris. It carried on extensive arbitration activities concerning international conflicts, and when the parties could not agree on the choice of a chairman they applied to the national committees in different countries for suggestions. When Sweden was asked I was often suggested, so I went to Paris repeatedly as arbitrator. There I also became familiar with the other activities of the International Chamber of Commerce and for some reason I established contact particularly with a group whose business was international trade terminology for freights, things called 'fob' and 'cif' etc. I became a member of that group and after some time its chairman. We published a collection of definitions of these terms, 'Incoterms.' All the time I was also nominated as an arbitrator. (Lagergren and Aldrich 2002: 311).

While belonging to the Swedish elite, Lagergren showed an ability to bridge different cultural and legal approaches (rather than his own national approach) when deciding commercial disputes. He rendered, for example, an oft-cited award in ICC Case No. 1110, a dispute brought by an Argentine individual against a British company for the payment of commissions. ${ }^{41}$ While dismissing the case for lack of jurisdiction in 1963, Lagergren did

37 See "History," Raoul Wallenberg Institute for Human Rights and Humanitarian Law. Available at: http://rwi.lu.se/about/history/ (accessed 10 April 2017).

38 See International Chamber of Commerce, Brochure No. 13 (First Congress, June 27 to July 1, 1921). Paris: ICC.

39 See International Chamber of Commerce, Brochure No. 31 (Resolutions Adopted at the Second Congress, March 1923). Paris: ICC. (International Commercial ArbitrationPractical Hints.

40 See International Chamber of Commerce (1935) International Commercial ArbitrationPractical Hints. Paris: ICC.

41 See “Argentine Engineer v. British Company, Award, ICC Case No. 1110,” (1994) 3 Arbitration International 282-94. 
not refer to a national law, but to the "good morals and international public policy" that prohibited the "bribing of Argentine officials for the purpose of obtaining the hoped-for business." 42 In doing so, he applied an overarching set of transnational norms and values (later named "transnational public policy") which he believed were common to the national legal systems at stake. In similar ways, Berthold Goldman was dubbed the "father" of the lex mercatoria, a set of global rules cutting across national legal systems that is applied-according to Goldman and others-to ICA (Goldman 1964).

Like Lagergren and Goldman, most of the individuals listed in Table 1 were successful as arbitrators because they were able to navigate between different legal systems, and to harmonize approaches that would otherwise remain in tension. Ernest Barda's obituary in the Bulletin de la Société de Législation Comparée emphasized that he "did a lot for the reconciliation between continental and AngloAmerican conceptions, and even more to promote an efficient cooperation between Italian lawyers and French lawyers." ${ }^{43}$ My point is that these individuals were part of a transnational elite; they did not depend on skills developed in national practice, but rather built their social power and legitimacy at the intersections of boundaries and traditions. These technical skills often came from their personal histories, educations, and career experiences across borders.

\section{Professional Eclecticism}

In addition to reconciling different national approaches, these arbitrators showed an ability to accumulate different professional activities, layering expertise that would help them manage the hybridization process that would subsequently unfold (as described further below). All these arbitrators had a main professional activity to which they added their activities as arbitrators. However, most of them also engaged in other professional activities as well. Ernest Barda's main profession was that of an attorney, but he also nurtured a strong academic interest through his involvement with the Société de législation comparée. Ernst Mezger was also a lawyer, but was involved with several academic societies as well, including the Institut de droit comparé at the University of Paris II (where he ended up teaching) and the Comité francais de droit international privé (of which he became the vice president). ${ }^{44}$ Although many arbitrators had a strong interest in academic life,

\footnotetext{
42 Id.

43 See Marc Ancel (1967) "Ernest Barda," 19/3 Revue Internationale de Droit Comparé 702.

44 See Otto Sandrock (1991) “Nachruf auf Ernst Mezger,” 90 ZVglRWiss 307-12.
} 
they were not "professional academics" in the sense that they did not draw regular income from a permanent position in a university or law school. As will be shown further below, modern arbitrators have followed the steps of these pioneers by cumulating different professional features.

The prototypes of hybridization were Paul van Reepinghen and Lazare Kopelmanas, who led parallel activities over their entire careers. Van Reepinghen obtained the most important number (28) of appointments as an arbitrator between 1922 and 1973. He was neither a professor nor an attorney but headed the legal department of the Federation of Belgian Industries (which later became the Federation of Belgian Enterprises in 1973), the main employers' confederation representing business interests in Belgium. ${ }^{45}$ Right from the beginning, the ICC sought to build ties with organizations such as the Federation of Belgian Industries, ${ }^{46}$ and it is likely that Paul van Reepinghen established strong connections with the ICC through that organization. In addition, he specialized in intellectual property law, and became the head of the International Association for the Protection of Intellectual Property's Belgian chapter, the leading organization "dedicated to the development and improvement of laws for the protection of intellectual property." 47 Under the auspices of the Federation of Belgian Industries, he later founded and headed the CEPANI (the Belgian Centre for Arbitration and Mediation) from 1969 until 1974. ${ }^{48}$ Van Reepinghen does not appear to have participated in any academic activity, nor was he affiliated with a law firm. And he does not match Dezalay and Garth's profile of the "grand old man," who drew intellectual prestige and charisma out of his academic position and did not display strong technical skills (Dezalay and Garth 1996: 34-35). Instead, his appointments were due to his connections with the business world, and his expertise in intellectual property law.

Lazare Kopelmanas too displayed a hybrid profile. He was mainly an international civil servant, working as a legal advisor to the United Nations in Geneva from 1949 until $1977 .{ }^{49}$ In this

45 Email from Mr. Laurent van Reepinghen dated 13 July 2016.

46 See International Chamber of Commerce 1935: 7: “In March 1935, its organization members numbered 868 Chambers of commerce, manufacturing associations, industrial organizations, banking unions, transport bodies, etc., belonging to 46 countries, in 32 of which they were represented by National Committees, a list of which appears on the cover."

47 See “About AIPPI,” http://aippi.org (accessed 16 August 2016).

48 Email from Mr. Laurent van Reepinghen dated 13 July 2016.

49 See Lazare Kopelmanas (1976), "L'application du droit national aux sociétés multinationales," in Collected Courses of the Hague Academy of International Law, Vol. 150. Leiden/ Boston: Brill/Nijhoff. 298. 


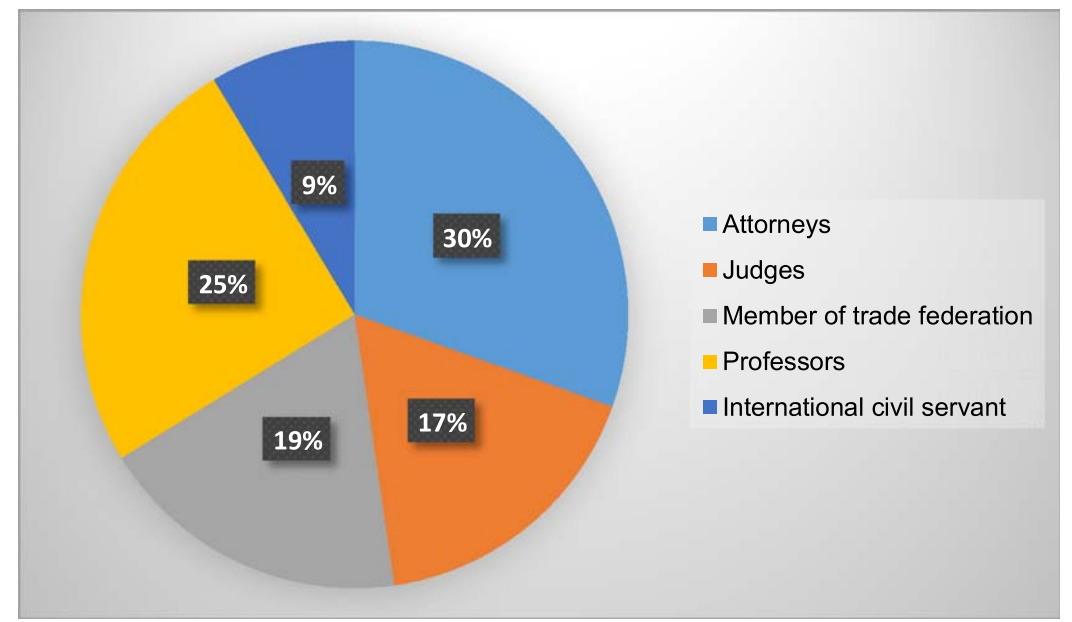

Fig 1. The Grand Old Men: Cumulative Number of Appointments per Profession (1922-1973).

capacity, he advised the United Nations throughout the negotiations that led to the European Convention on International Commercial Arbitration (1961). ${ }^{50}$ In addition, he constantly had stints in various universities around the world: the Centre National de la Recherche Scientifique in France (1945-1949), the Hague Academy of International Law (1950, 1957-1958, 1976), Yale Law School (1957-1958), the University of Paris (1960-1962), and the University of Geneva (1971-1973). ${ }^{51}$ Although Kopelmanas never held a permanent professorship in any of these institutions (and therefore could not draw prestige from his academic activities in a local context), his ability to navigate and teach in different legal systems built his legitimacy as a transnational legal expert. As will be shown below, hybrid profiles such as those of Kopelmanas and Van Reepinghen have become a stable feature among commercial arbitrators.

\section{Professional Diversity}

The dataset also contains information on appointments by profession. Figure 1 provides a breakdown of these cumulative

50 See Ottoarndt Glossner (1995), “Institutionelle Schiedsrichterernennung - Das Besondere Komité des Europäischen Übereinkommens über die Handlesschiedsgerichtsbarkeit von Genf vom 21. April 1961," in von Westphalen F. G., et al., eds., Lebendiges RechtVon den Sumerern bis zur Gegenwart - Festschrift für Reinhold Trinkner zum 65. Geburtstag. Heidelberg: Verlag Recht und Wirtschaft. 555.

51 See Lazare Kopelmanas (1976), "L'application du Droit National Aux Sociétés Multinationales," in Collected Courses of the Hague Academy of International Law, Vol. 150. Leiden/ Boston: Brill/Nijhoff. 298. 
numbers by profession (attorneys, judges, members of trade federations, professors, and international civil servants).

Figure 1 shows that law professors were not the dominating group among top ICC arbitrators. In fact, attorneys held the most important share of all appointments (30 percent). In addition, several other legal professions (judges, members of trade federations, international civil servants) were represented among the pool of arbitrators. In an early review of Dealing in Virtue, an arbitration insider (who would later become the Chairman of the ICC International Court of Arbitration) stressed that Dezalay and Garth had missed the fact that the older generation too drew their symbolic capital out of "long experience as contentious lawyers," and that some of them "developed academic careers to complement their roles as active practitioners" (Beechey 1997: 573). An analysis of the "grand old men" based on an exhaustive review of ICC cases between 1922 and 1973, therefore, confirms that their overlapping identities were much more diverse and complex than the figure of the old continental professor identified by Dezalay and Garth, who had built power and legitimacy on a local status and prestige. On the contrary, many of these "grand old men" were not powerful in their national systems, not least, because they were immigrants. Their transnational legitimacy was rooted in the ambiguous, complex identity of the marginal who is skilled at working "in between" different systems, and fashioning new ones.

\section{The Evolution of ICC Arbitration}

Having offered a snapshot of these "grand old men," let us now consider the big picture: the distribution of all appointments at the ICC between 1922 and 1972. Figure 2 presents a picture of these appointments divided into five sub-periods and broken down by profession.

\section{The Judicialization of ICC Arbitration}

Graph 2 confirms several conclusions drawn from Table 1 and Graph 1. Professors were only a minority among all appointees, even though their relative weight steadily grew over time. Graph 2 also confirms that attorneys were the dominant group among ICC arbitrators after the Second World War, and that their relative importance also increased. Conversely, the proportion of engineers/experts, businessmen/ corporate executives and members of trade federations/unions dropped to insignificant levels. When considering the last sub-period (1963-1972), attorneys, judges, and professors 


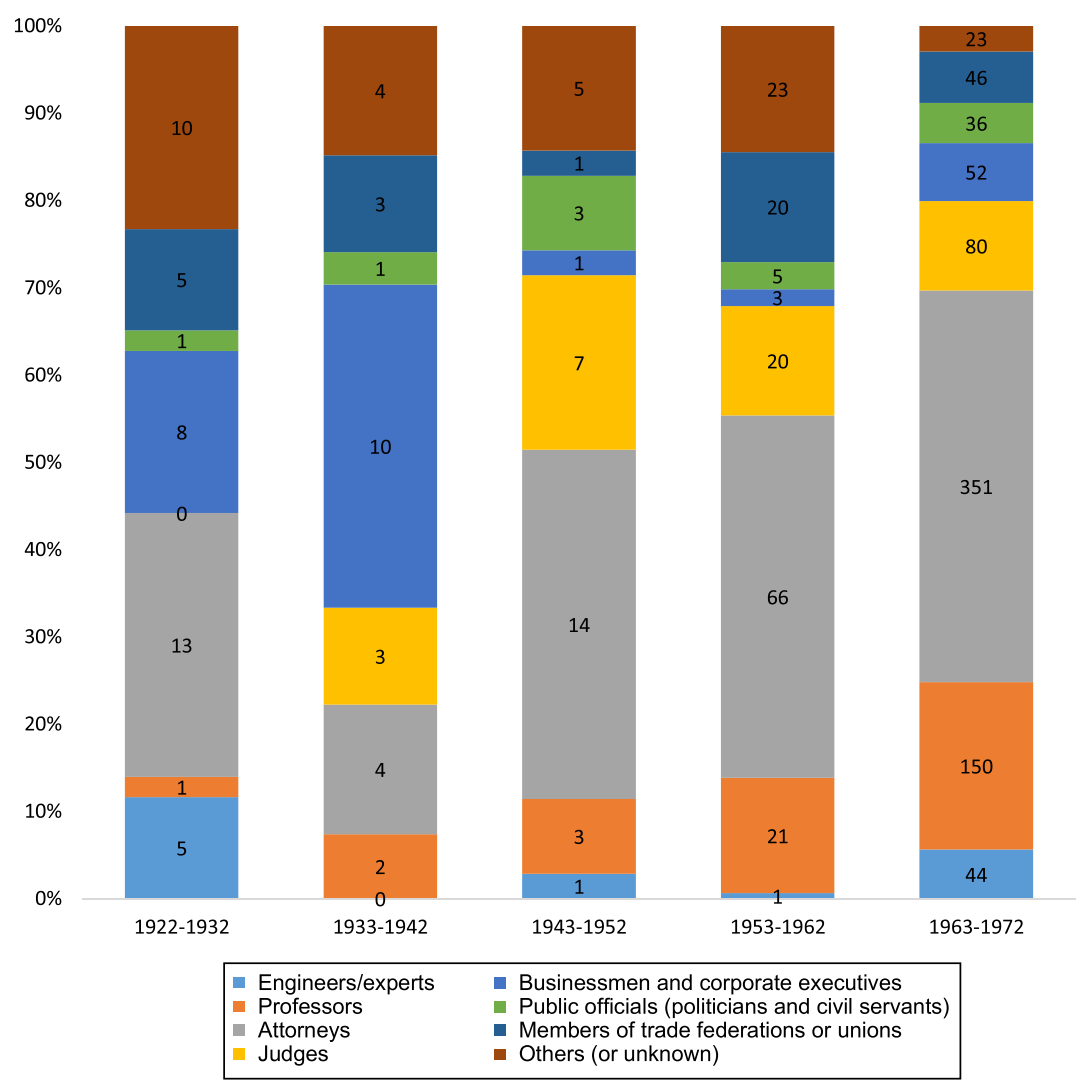

Fig 2. The Sociological Evolution of ICC Arbitrators.

accounted for more than 74 percent of all appointments. In other words, the influence of legal specialists grew over time to the point where business specialists held only a small share of all appointments.

The growing influence of legal specialists can be considered a sign of the steady judicialization that ICA incurred through the twentieth century (Grisel et al. 2016; Stone Sweet and Grisel 2017). As the financial stakes of business disputes grew, and as parties became increasingly sophisticated, the demand for legal expertise and consistency also grew. This can be observed, for instance, in the growing length of ICC procedural rules, which progressively expanded to anticipate a broader range of procedural difficulties (Stone Sweet and Grisel 2017). Dezalay and Garth argued that the judicialization of arbitration occurred in the 1980s, when "young technocrats" arrived to Continental Europe with Anglo-American law firms, bringing with them the baggage of litigation techniques borrowed from common law 
systems (Dezalay and Garth 1996: 54-57). However, AngloAmerican law firms were already heavily invested in ICC arbitration prior to the $1970 \mathrm{~s},{ }^{52}$ and several arbitrators were affiliated with barrister chambers in London. ${ }^{53}$ In addition, leading arbitrators commonly sought to build bridges between the common law and civil law traditions through comparative analysis. ${ }^{54}$

In fact, many of the historical figures of arbitration in the common law world presented the same hybrid features as the leading arbitrators in Table 1. For instance, Martin Domke is a prime example of a "secant marginal," whose career blossomed in the common law world. ${ }^{55}$ Domke was born and educated as a lawyer in Germany, before fleeing Nazi persecution for France and then the United States. ${ }^{56}$ He later became an adjunctProfessor of Law at New York University and the Vice-President (and Director of Legal Research) of the American Arbitration Association. ${ }^{57}$ His "unique role" in the development of ICA was described in 1967 as one of "a comparative lawyer of considerable distinction," associated with "the shrewd down-to-earth salesman of a valuable commodity as yet too little known but capable of being proved superior to its competitors." 58

Several towering figures in the United Kingdom shared similar career trajectories. Clive Schmitthoff grew, studied, and worked in Germany before moving to the United Kingdom and becoming a prominent law professor who theorized-at the same time as Berthold Goldman, but across the Channel-the lex mercatoria. ${ }^{59}$ Even more striking is the case of Michael Kerr, a

52 This involvement was twofold: these firms represented parties in ICC proceedings, and some arbitrators were attorneys in these firms. I counted four prominent English solicitors' firms and two prominent U.S. law firms. All these firms (or their successors) currently have successful arbitration practices.

53 I counted at least three barrister chambers.

54 For instance, Lazare Kopelmanas taught in the United States (Yale Law School), Ottoarndt Glossner studied in the United Kingdom (Liverpool), and Ernest Barda wrote his doctoral dissertation on specific performance under English law.

55 Other examples include Andreas Lowenfeld (born in Germany) and Hans Smit (born in the Netherlands), who were both actively involved in legal academia (with professorships at New York University and Columbia University) and legal practice (as international arbitrators). They both cultivated a strong interest for comparative law.

56 Certified Award rendered by the Claims Resolution Tribunal In re Holocaust Victim Assets Litigation Case No. CV96-4849 (in re Accounts of Martin Domke) on August 31, 2005.

57 See Eugenio Minoli et al. (1967), "Introduction," in Sanders, P., ed., International Arbitration - Liber Amicorum for Martin Domke. The Hague: Martinus Nijhoff. vii.

58 Ibid.

59 See John N. Adams (2004) "Clive M. Schmitthoff (1903-1990)," in Beatson J., et al., ed., Jurists Uprooted: German-Speaking Emigré in Twentieth Century Britain. Oxford: Oxford University Press. 
German refugee who climbed the social ladder of British legal elites to become a successful barrister and judge, and the first president of the London Court of International Arbitration in $1985 .^{60}$ Kerr thought that his foreign origin was a "crucial characteristic which could not be shaken off or ignored" throughout his career in England. ${ }^{61}$

This cross-fertilization of the civil law/common law systems can also be seen in the emergence of arbitral procedures that have been in large part harmonized (through procedural transplants from the common and civil law traditions) rather than Americanized (Helmer 2003; Jemielnak forthcoming). This process is a measure of the judicialization, a process that began to unfold decades before the period emphasized by Dezalay and Garth. To take just one obvious example, ICA's hybrid evidentiary system accreted long before the 1980s, through the blending of the civil law tradition, which takes a restrictive stance toward discovery, with the common law tradition, where judges possess the power to compel disclosure (Stone Sweet and Grisel 2017: 98-99). This "institutional bricolage" led to the creation of a sui generis procedure, called "document production." The system, widely used in ICA, has been described as "one of the most remarkable examples of a merger between different ... procedural approaches." ${ }^{\circ 2}$ Dezalay and Garth interpreted the "emphasis on fact-finding" as a sign of the "Americanization" of international arbitration (Dezalay and Garth 1996: 62). In fact, they observed a middle point in an institutionbuilding process already underway.

In this context, "secant marginals" are particularly well equipped to cherry-pick and combine elements drawn from diverse legal traditions. Consider for example the debates surrounding the lex mercatoria in the 1960s. Dezalay and Garth interpreted the lex mercatoria as a doctrinal construction of the "grand old men" from France and Switzerland, who sought to preserve their "corporatist control over the profession" by promoting the application of a less formal system of arbitration based largely on equity (Dezalay and Garth 1996: 39-42). In fact, prior to the

${ }^{60}$ See Michael Kerr (2002) As Far as I Remember. Oxford/Portland: Hart Publishing. 324.

61 Id., 239: "[...] in yesterday's England a foreign origin was a crucial characteristic which could not be shaken off or ignored. Despite our naturalisations, Judy and I would never have been considered for any job in the Foreign or Diplomatic Service, and I used to worry whether the same might secretly apply to becoming a QC or a judge. In the end it didn't. But perhaps nearly: I was once told in 1972 that I was the first foreign-born High Court judge to have been appointed since the time when some Norman judges were brought over from France in the reign of Henry II."

62 Gabrielle Kaufmann-Kohler (2003) "Globalization of Arbitral Procedure," 36 Vanderbilt Journal of Transnational Law 1313, 1325. 
1960s, most ICC awards were rendered on the basis of equity and trade usages (rather than formal legal norms) (Grisel et al. 2016: 428-29). It is in this context that "secant marginals" based in civil law and common law countries (Berthold Goldman in France, and Clive Schmitthoff in England), began to design the lex mercatoria as a global set of legal norms, drawn from the main legal systems. ${ }^{63}$ Their goal was to apply a set of general principles of law (often through the formalization of trade usages), rather than equity, to the merits of the disputes submitted to ICA (Stone Sweet and Grisel 2017: 80-118). Dezalay and Garth saw remnants of an equity-based system ran by "grand old men," but seemed to have missed entirely the efforts of theorists and practitioners of the lex mercatoria to build an autonomous and inherently legal order in order to make ICA a true substitute for courts-way before the 1980s. These findings confirm, dispositively in my view, that the judicialization process did not result from the "victory" of common lawyers and their subsequent domination of the field, but from a broader process that unfolded over a longer temporal scale.

\section{The Emergence of an ICC "Arbitration Club"}

Another striking aspect of ICC arbitration is the growing importance of arbitrators' re-appointments, a direct indicator of membership in the elite "club." To track the practice of reappointments over time, I compiled data on the respective proportion of first appointments and re-appointments between 1922 and 1972, broken down into 5 sub-periods. I also added the number of all appointments (whether first appointments or reappointments) for each sub-period in Figure 3.

Figure 3 charts the proportion of re-appointments, which has grown steadily after the Second World War, reaching almost 50 percent of all appointments during the last sub-period (19631972). One explanation for this growing practice was the rapid development of ICC arbitration after the Second World War and the need to constitute tribunals quickly. ${ }^{64}$ These constraints naturally led to the appointment of those who were known to the ICC (or to the disputing parties). Another explanation is the

63 Pieter Sanders described the lex mercatoria as "principles common to the law of civilised nations" in 1967. See Pieter Sanders, "Recent Developments in International Commercial Arbitration." Available at: http://www.arbitration-icca.org/media/0/121 19973498790/002.pdf (accessed 19 April 2017). He also gave a speech at the ICC Commission on International Arbitration on 6 May 1968, on the "role of arbitration in developing international trade law," where he made recommendations to the ICC on how to develop the lex mercatoria (see ICC Document $\left.\mathrm{N}^{\circ} 420 / 162\right)$.

64 It should be noted that most arbitrators were appointed by the ICC Court of Arbitration and that some of them were appointed by the disputing parties themselves. 


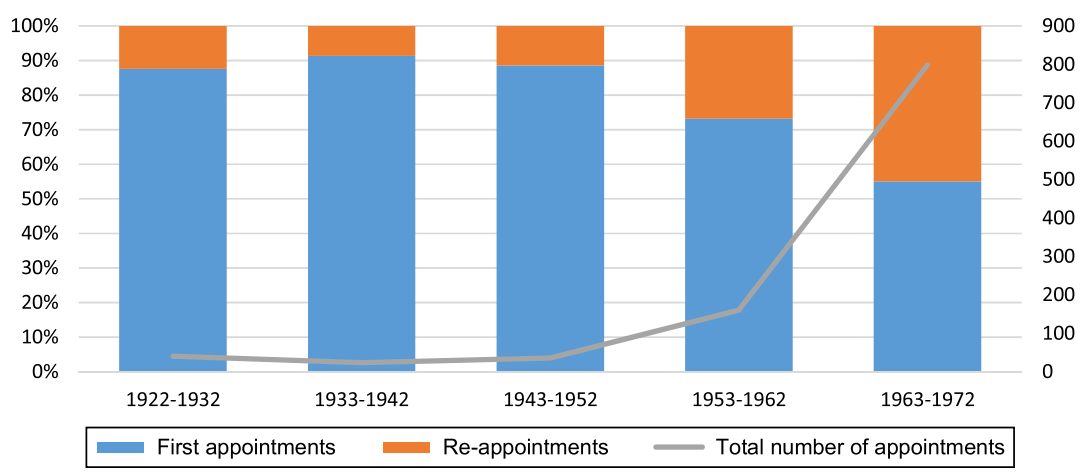

Fig 3. The Emergence of the ICC Arbitration Club. [Color figure can be viewed at wileyonlinelibrary.com]

growing practice of financial compensation for the arbitrators' work (see Grisel et al. 2016: 411, 431-32), which created an incentive for arbitrators to be re-appointed.

In either case, the importance of re-appointments is key to understanding the emergence of a club of arbitrators. The chances of an individual to draw income and prestige from reappointments grew significantly once he (and more rarely, she ${ }^{65}$ ) had already been appointed. As a consequence, it became critical for these individuals to belong to the "arbitrators' club," that is, the group of individuals who enjoyed frequent re-appointments. Arbitrators who wanted to belong to the "club" used different techniques to obtain re-appointments: they emphasized their differences (and, hence, their comparative advantage) with the "grand old men" (as reported by Dezalay and Garth) while mimicking features that had brought success to the same. In particular, they sought to cumulate different professional affiliations that signaled their ability to navigate across different legal systems and build transnational legitimacy, just as the "grand old men" had done in the past. The second dataset provides key information on the sociological features of the "young technocrats' 20 years later. This dataset shows that the hybrid features of leading arbitrators—which appeared between the 1950s and 1970s- have been reproduced over time.

\section{Hybridization and Birth of a Legal Profession}

The second dataset is based on information supplied by the Who's Who List of the Most Highly Regarded Individuals in Commercial

65 I noted the names of two women (both attorneys) who were appointed arbitrators during this time period. One was appointed only once, and the other one was appointed several times. 
Table 2. The Young Technocrats, 20 Years Later (2015)

\begin{tabular}{|c|c|c|c|c|c|c|}
\hline Name & Gender & Nationality & Birth & $\begin{array}{l}\text { Academic } \\
\text { Activities }\end{array}$ & $\begin{array}{l}\text { Position in } \\
\text { an Arbitral } \\
\text { Institution }\end{array}$ & $\begin{array}{c}\text { Attorney } \\
\text { or Barrister }\end{array}$ \\
\hline Judith Gill & $\mathrm{F}$ & UK & 1959 & $\mathrm{Y}$ & $\mathrm{Y}$ & $\mathrm{Y}$ \\
\hline Bernard Hanotiau & M & Belgium & 1947 & $\mathrm{Y}$ & $\mathrm{Y}$ & Y \\
\hline Gary Born & M & USA & 1955 & $\mathrm{Y}$ & $\mathrm{Y}$ & $\mathrm{Y}$ \\
\hline Toby Landau & M & UK & 1967 & $\mathrm{Y}$ & $\mathrm{Y}$ & $\mathrm{Y}$ \\
\hline Audley Sheppard & M & New Zealand & 1960 & $\mathrm{Y}$ & $\mathrm{Y}$ & $\mathrm{Y}$ \\
\hline AJ van den Berg & M & Netherlands & 1949 & $\mathrm{Y}$ & $\mathrm{Y}$ & $\mathrm{Y}$ \\
\hline Emmanuel Gaillard & M & France & 1952 & $\mathrm{Y}$ & $\mathrm{Y}$ & $\mathrm{Y}$ \\
\hline L. Yves Fortier & M & Canada & 1935 & $\mathrm{~N}$ & $\mathrm{Y}$ & $\mathrm{Y}$ \\
\hline VV Veeder & M & UK & 1948 & $\mathrm{Y}$ & $\mathrm{Y}$ & $\mathrm{Y}$ \\
\hline David W. Rivkin & M & USA & 1955 & $\mathrm{~N}$ & $\mathrm{Y}$ & $\mathrm{Y}$ \\
\hline Pierre Bienvenu & M & Canada & 1957 & $\mathrm{~N}$ & $\mathrm{Y}$ & $\mathrm{Y}$ \\
\hline $\begin{array}{l}\text { Gabrielle } \\
\quad \text { Kaufmann-Kohler }\end{array}$ & $\mathrm{F}$ & Switzerland & 1952 & $\mathrm{Y}$ & $\mathrm{Y}$ & $\mathrm{Y}$ \\
\hline Alexis Mourre & M & France & 1963 & $\mathrm{Y}$ & $\mathrm{Y}$ & $\mathrm{Y}$ \\
\hline Stephen Jagusch & M & New Zealand & 1967 & $\mathrm{Y}$ & $\mathrm{Y}$ & Y \\
\hline Constantine Partasides & M & UK & 1969 & $\mathrm{Y}$ & $\mathrm{N}$ & Y \\
\hline Henri Alvarez & M & Canada & 1954 & $\mathrm{Y}$ & $\mathrm{Y}$ & $\mathrm{Y}$ \\
\hline Klaus Sachs & M & Germany & 1951 & $\mathrm{Y}$ & $\mathrm{Y}$ & $\mathrm{Y}$ \\
\hline Yves Derains & M & France & 1945 & $\mathrm{Y}$ & $\mathrm{Y}$ & Y \\
\hline Laurent Lévy & M & Switzerland/Brazil & 1948 & $\mathrm{Y}$ & $\mathrm{Y}$ & $\mathrm{Y}$ \\
\hline Julian Lew & M & UK & 1948 & $\mathrm{Y}$ & $\mathrm{Y}$ & Y \\
\hline Donald Donovan & M & USA & 1955 & $\mathrm{Y}$ & $\mathrm{Y}$ & $\mathrm{Y}$ \\
\hline Jan Paulsson & M & France & 1949 & $\mathrm{Y}$ & $\mathrm{Y}$ & Y \\
\hline Michael Pryles & M & Australia & 1945 & $\mathrm{Y}$ & $\mathrm{Y}$ & $\mathrm{Y}$ \\
\hline Eduardo Silva Romero & M & Colombia/France & 1971 & $\mathrm{Y}$ & $\mathrm{Y}$ & Y \\
\hline William Rowley & M & Canada & 1943 & $\mathrm{Y}$ & $\mathrm{Y}$ & $\mathrm{Y}$ \\
\hline
\end{tabular}

Arbitration (2015). ${ }^{66}$ These individuals are routinely appointed as arbitrators in commercial disputes (at the ICC or elsewhere), and some also have a substantial practice as attorneys in ICA. This second dataset is not specific to the ICC but cuts across the different practices of ICA. ${ }^{67}$ As such, it provides a sociological picture of the most successful individuals who currently operate in this field, and allows us to put the findings drawn from the first dataset to a temporal test. To a large extent, these individuals embody the current leadership of today's "club."

The second dataset reflects the capacity of the new leaders to navigate across various practices and legal systems (Bhatia 2011: 80; Bhatia et al, 2012), and provides support for the view that professional "hybridization" in ICA has taken place. The 25 individuals in Table 2 present common sociological features: all come

66 The methodology for establishing this list is described as follows on the Who's Who Web site: "This year's edition identifies world-class practitioners in 89 countries - a wider geographical spread than ever before, which reflects the ever-growing use and sophistication of international arbitration. In total, we list 812 arbitrators and counsel from 481 firms as leaders in this field; in this section we pick out the firms with the most listed lawyers in order, as well as the individuals who scored most highly in our voting." (see http://whoswholegal.com/news/analysis/article/32630/arbitration-2016-analysis/ (accessed21 August 2016).

67 In this regard, the recent decision of the ICC International Court of Arbitration to publish the names of its arbitrators opens avenues for future research. 
from or live in the developed world, roughly all are the same age (with an average of 61 years old and a standard deviation of 8.85 years ${ }^{68}$ ), and they generally have elite educational backgrounds. For instance, eight of them hold (at least) one degree from the following four universities: Oxford, Cambridge, Yale, or Harvard. ${ }^{69}$ Another striking aspect is the domination of men over this global elite (23 out of 25 individuals).

This domination is not new. My data on the ICC arbitrators nominated between 1922 and 1973 show five appointments of only two female arbitrators (over more than a thousand appointments of arbitrators during the same time period). None of these two women were part of the list of elite arbitrators set out in Table 1. In addition, these women did not share the features of the "secant marginals." 70 By contrast, the two female arbitrators in Table 2 (Gabrielle Kaufmann-Kohler and Judith Gill) are members of the current elite of ICA, and share similar social features as the rest of the group (in terms of education, geographic background and professional affiliations). This data tends to show that although male domination over the arbitration elite is still overwhelming, ${ }^{71}$ some female arbitrators have developed successful power strategies to integrate the group.

More specifically, members of the current elite-irrespective of whether they are men or women-appear to have leveraged their social capital to obtain positions at the intersection of various systems and gain traction in the transnational space discovered by the "secant marginals." More specifically, these individuals have built transnational legitimacy along the paths cleared-almost incidentally-by their elders by combining various professional strands: an affiliation with a bar, a significant display of academic activities, and strong connections to arbitral institutions. Unlike the "secant marginals," however, the new leading figures have consciously designed their cosmopolitan journey to build transnational legitimacy. Once they achieved this goal, some of these individuals even translated their transnational

68 Their age is roughly the same as the individuals listed in Table 1 (61.2 years old with a standard deviation of 4 years).

69 Judith Gill, Toby Landau, Audley Sheppard, L. Yves Fortier, VV Veeder, David W. Rivkin, Constantine Partasides, Jan Paulsson.

70 One of these female arbitrators (Maria Plum) gathered four appointments in 1960 and 1961 (she died in 1962). Plum was a German lawyer (and a former member of the NSDAP) who did not share any feature of the "secant marginals." The other female arbitrator (Carmela Correale, USA) only obtained one appointment.

71 It should be noted in this regard that various actors of international arbitration have made a "pledge" to improve the representation of women in 2016, see http://www.arbitrationpledge.com/pledge (accessed 13 April 2017). 
legitimacy back into their national systems of origins in a feedback loop of legitimacy that will be further discussed below.

\section{Affiliation with a Bar}

All of these individuals, without exception, are barristers or attorneys. While this does not mean that all currently practice as counsel, they have all kept their affiliation either to a bar (even without practicing), a law firm, or a barrister chamber. Nine of them generate sufficient income as arbitrators (more rarely as counsel in arbitral proceedings) to run their own firms, usually of a relatively small size. ${ }^{72}$ Five of them are barristers in chambers located in London. ${ }^{73}$ Six of them are Queen's Counsel in England and Wales, an honorary title for the most eminent law practitioners. $^{74}$

Most of these individuals appear to use their law firm or barrister chamber more as a platform for various activities (predominantly their activities as arbitrators) than as a place to practice the profession of attorney. ${ }^{75}$ This element is a distinguishing feature compared with the individuals in the first dataset, most of whom had a clear professional affiliation (to which they added their activities as arbitrators). By contrast, the individuals listed in Table 2 are professional arbitrators who have assembled features of various professional activities while sharing their affiliation with a bar as a distinctive feature. The affiliation of these individuals to a bar, which could be interpreted as a sign of legal vernacularism, should not obfuscate their multinational backgrounds. In fact, nine of the individuals in Table 2 are licensed to practice law

72 Bernard Hanotiau (Hanotiau and van den Berg), Albert Jan van den Berg (Hanotiau and van den Berg), Yves Fortier (Cabinet Yves Fortier), Gabrielle Kaufmann-Kohler (Lévy Kaufmann-Kohler), Constantine Partasides (Three Crowns LLP), Yves Derains (Derains and Gharavi International), Laurent Lévy (Lévy Kaufmann-Kohler), Jan Paulsson (Three Crowns LLP), Michael Pryles (Dispute Resolution Services PTY Ltd).

73 Toby Landau (Essex Court Chambers), VV Veeder (Essex Court Chambers), Julian Lew (20 Essex Street), Michael Pryles (20 Essex Street), William Rowley (20 Essex Street).

74 Judith Gill, Toby Landau, Audley Sheppard, VV Veeder, Stephen Jagusch, Constantine Partasides.

75 Michael Kerr, the first president of the LCIA, appears to have been a precursor in this regard. See Michael Kerr (2002) As Far as I Remember (Oxford/Portland: Hart Publishing), 328: "Then I finally left the courts and returned to Chambers. [...] The then head, Tony Diamond, one of the original tenants, and the senior Clerk, David Grief, both asked me to come back as a full-time arbitrator. At that time this was something unprecedented for a retired Lord Justice. [...] Chambers gave me a small room and full secretarial back-up, with typing, fax and everything. In return I paid them the same percentage of my receipts as all other members of Chambers, together with the same Clerk's fees. We were all very happy with the arrangement." 
in several jurisdictions. ${ }^{76}$ Eleven of them are partners in global law firms that employ hundreds (sometime thousands) of attorneys in all major cities throughout the world. ${ }^{77}$

The uniformity across this pool of individuals confirms the finding in the first dataset according to which attorneys have progressively dominated the game of ICA. Through their affiliation with one or several bars, leading individuals signal their lawyering skills to the arbitration market. As previously noted, the need to display technical skills results from the judicialization process that has unfolded over several decades in ICA rather than the competition between attorneys and law professors (Stone Sweet and Grisel 2017). In fact, the competition between attorneys and law professors seems exaggerated when considering that almost all the individuals listed in Table 2 have also acquired the credentials of chaired professors (in addition to their bar affiliations).

\section{Academic Activities}

Almost all the individuals (23 out of 25) listed therein have built a portfolio of academic activities (Table 2). Nine of them hold doctoral degrees in law. ${ }^{78}$ Most of these individuals pride themselves on teaching in various law schools and universities around the world. Four individuals began their careers as law professors and kept affiliations with law schools throughout their careers. ${ }^{79}$ Ten individuals, although not originally trained as law professors, obtained honorary, visiting or adjunct professorships at a later stage of their careers. ${ }^{80}$ Seven individuals have written reference textbooks or monographs on ICA. ${ }^{81}$ All of these 22 individuals regularly publish in academic journals on the subject of ICA. In that sense, the new generation of leading arbitrators appears to have followed the steps of figures such as Ernest

76 Bernard Hanotiau, Toby Landau, Audley Sheppard, Albert Jan van den Berg, Gabrielle Kaufmann-Kohler, Stephen Jagusch, Julian Lew, Jan Paulsson, Eduardo Silva Romero.

77 Judith Gill (Allen and Overy), Gary Born (WilmerHale), Audley Sheppard (Clifford Chance), Emmanuel Gaillard (Shearman and Sterling), David W. Rivkin (Debevoise and Plimpton), Pierre Bienvenu (Norton Rose Fulbright), Stephen Jagusch (Quinn Emanuel Urquhart and Sullivan), Henri Alvarez (Fasken Martineau), Klaus Sachs (CMS Hasche Sigle), Donald Donovan (Debevoise and Plimpton), Eduardo Silva Romero (Dechert).

78 Bernard Hanotiau, Albert Jan van den Berg, Emmanuel Gaillard, Gabrielle Kaufmann-Kohler, Klaus Sachs, Laurent Lévy, Michael Pryles, Eduardo Silva Romero.

79 Bernard Hanotiau, Albert Jan van den Berg, Emmanuel Gaillard, and Gabrielle Kaufmann-Kohler.

80 Gary Born, Toby Landau, VV Veeder, Klaus Sachs, Laurent Lévy, Julian Lew, Donald Donovan, Jan Paulsson, Michael Pryles, and Eduardo Silva Romero.

81 Gary Born, Albert Jan van den Berg, Emmanuel Gaillard, Gabrielle KaufmannKohler, Constantine Partasides, Julian Lew, Jan Paulsson. 
Barda, Lazare Kopelmanas, or Ernst Mezger (Table 1), who combined practical and academic interests throughout their careers.

The involvement and association with academic institutions appears to be of primal importance for arbitrators. It signals their legal sophistication and ability to engage with lawyers originating from various countries. The web page of one of these arbitrators is telling in this regard:

Mr. Born is an Honorary Professor of Law at the University of St. Gallen, Switzerland and Tsinghua University. He has also taught at Harvard Law School, University of Pennsylvania Law School, Stanford Law School, Georgetown University Law Center, National University of Singapore, Peking University School of Transnational Law, University of Virginia College of Law, University College London and the University of Arizona College of Law.

Mr. Born is a member of the American Law Institute and of the Board of Trustees of the British Institute for International and Comparative Law. He has served on the Executive Council of the American Society of International Law, the Advisory Committee of the ALI's Restatement of US International Arbitration Law, the Advisory Committee of the ALI Restatement of US Foreign Relation Law (Fourth) and as co-chair of the ABA International Section, Committee on International Aspects of Litigation. He is also a Vice President of the American Society of International Law $[\ldots]^{82}$

This long list of academic affiliations shows the wide recognition of this arbitrator in various academic settings (universities, scientific societies, and academic journals) around the world (America, Europe, Asia, and Africa). An academic affiliation matters, burnishing the image of a legal specialist who can navigate with equal ease across various legal systems. By cultivating affiliations with academic institutions around the world, leading arbitrators signal their acculturation with multiple legal systems, their ability to apply various sets of domestic laws, and their familiarity with different lawyering styles. In addition, these individuals have not only anchored their legitimacy at the local level through academic affiliations, but they have also built legitimacy at a level that is specifically transnational by nurturing numerous connections with arbitral institutions.

82 See Profile of Mr. Gary Born, https://www.wilmerhale.com/gary_born/ (accessed 20 August 2016). 
Table 3. Super-Arbitrators and Arbitral Institutions

\begin{tabular}{lccccccccc}
\hline & \multicolumn{8}{c}{ Number of Positions in Leading } \\
\cline { 2 - 11 } & 0 & 1 & 2 & 3 & 4 & 5 & 6 & 7 & Total \\
\hline Number of arbitrators also listed in Table 2 & 1 & 2 & 11 & 6 & 2 & 2 & 0 & 1 & 25
\end{tabular}

\section{Connections with Arbitral Institutions}

Connections with arbitral institutions are not simply anecdotal. They are quasi-systematic, at the highest levels of responsibility in the leading arbitral institutions around the world (Table 2). One counts 1 President of the ICC International Court of Arbitration, 2 Presidents of the Singapore International Arbitration Court, 3 Presidents of the London Court of International Arbitration, and 1 Secretary General of the ICC International Court of Arbitration.

Table 3 summarizes the number of positions in leading arbitral institutions that have been held - in the present and in the past-by the individuals listed in Table $2 .{ }^{83}$ Most of these people have accumulated (in the present or in the past) several positions in leading arbitral institutions. Almost 90 percent (22 out of 25) of those listed in Table 2 held two or more positions in leading arbitral institutions. One of these individuals has even held seven positions in these institutions. ${ }^{84}$ Again, the importance of the connections built with arbitral institutions was anticipated by the pioneers at the ICC, as shown by the examples of Paul van Reepinghen, who created the CEPANI in Belgium in 1969, and Ottoarndt Glossner, who chaired the ICC's Commission on International Commercial Arbitration before founding the German Institute of Arbitration in 1974. The many connections of leading individuals with arbitral institutions reflect the institutionalization of the transnational field: leading arbitrators and institutions owe reciprocal allegiances to one another and build legitimacy by nurturing these connections at a level that is specifically transnational.

\section{Feedback Loop of Legitimacy}

The data simply do not support the story told by Dezalay and Garth: ICA was built by secant marginals and not by local elites.

83 These positions include inter alia president, vice president, member of the court, member of the board, and member of a commission.

84 Michael Pryles has been member of the SIAC Court, President of the SIAC Court, Chairman of SIAC, member of the HKIAC International Advisory Board, member of the LCIA Court, member of the DIAC Board of Trustees, and member of the ICC Court (see http://michaelpryles.com/appointments/ (accessed 20 August 2016). 
Once the former acquired legitimacy at the transnational level, many managed to translate it into status at the local level. As an ultimate step of the globalization process, the distinction between local and transnational elites seems to be increasingly blurry, as leading individuals can diffuse social capital from the local to the global and vice versa.

There are several prominent examples of this feedback loop. Gabrielle Kaufmann-Kohler, a Swiss national, was appointed to the Board of Directors of UBS, the largest Swiss bank, in 2005. While other individuals in Table 2 have been board members of companies in their home countries (notably, L. Yves Fortier in Canada), the global standing of Gabrielle Kaufmann-Kohler seems to have been a key element in her appointment as a board member of UBS. In announcing the news, UBS stated:

Gabrielle Kaufmann-Kohler is a practicing attorney and partner with Schellenberg Wittmer as well as a Professor of private international law at University of Geneva Law School. She is admitted to the New York State Bar and the Geneva Bar and holds a doctorate of the University of Basle. Previously she has been a partner of Baker \& McKenzie and a legal adviser at UBS in New York. She acts as an international arbitrator in commercial and investment disputes and sports cases and was ranked among the top ten arbitrators worldwide in a 2005 survey by "The American Lawyer." ${ }^{\circ 5}$

Consider the study of the six individuals in Table 2 who are Queen's Counsel in England and Wales. The title of Queen's Counsel is honorary, and it rewards the most eminent members of the legal profession in England and Wales. It is a marker of "excellence in advocacy in the higher [English and Welsh] courts," 86 and of the British legal elite (Kauppi and Madsen 2013: 145). The title is, par excellence, the sign of belonging to a closed group of local elites who display specific features that can only be fully appreciated by local insiders. One of these specific features is the exercise of the profession of barrister, which is considered to be the aristocracy of the British legal profession (in contradistinction to the profession of solicitor). In fact, only barristers were allowed to apply for the award of Queen's Counsel

85 See "UBS announces board nominations and executive appointments" (December 14, 2005). Available at: https:/www.ubs.com/global/de/about_ubs/investor_relations/ releases/adhocre/new_display_page_adhocre.html/en/2005/12/14/ubs_announces_board_ nominations_and_executive.html (accessed 15 December 2016).

86 See the official website "QC Appointments," Available at: http://www.qcappointments.org (15 December 2016). 
Table 4. The appointment of solicitors as Queen's Counsel in England \& Wales (2008-2017)

\begin{tabular}{lcccccccccc}
\hline Year & $08 / 09$ & $09 / 10$ & $10 / 11$ & $11 / 12$ & $12 / 13$ & $13 / 14$ & $14 / 15$ & $15 / 16$ & $16 / 17$ & Total \\
\hline Applicants & 4 & 10 & 5 & 2 & 2 & 7 & 9 & 13 & 13 & 65 \\
Appointments & 3 & 1 & 2 & 0 & 1 & 5 & 5 & 3 & 6 & 26 \\
$\begin{array}{c}\text { Arbitration specialists } \\
\text { among appointees }\end{array}$ & 3 & 0 & 1 & 0 & 1 & 5 & 5 & 3 & 5 & 23 \\
\hline
\end{tabular}

prior to 1995. Since 1996, when solicitors were invited to apply for the award of Queen's Counsel, 98.2 percent of successful applicants were barristers. ${ }^{87}$ The data (Table 2) are striking when considered in this light. Of the six individuals who obtained the title of Queen's Counsel in Table 2, only two are barristers, ${ }^{88}$ and four are solicitors. ${ }^{89}$ Although the pool is too limited to draw general conclusions, it would appear that these four individuals were able, against the odds, to translate their formidable global legitimacy into the finest mark of local elitism: the title of "Queen's Counsel."

To further explore this possibility, I have compiled data on the solicitors who have successfully applied for the title of Queen's Counsel since 2008 (Table 4). Of the 26 solicitors who were appointed as "Queen's Counsel" during this time period, 23 were specialists in ICA. Arbitrators have translated their transnational success into a vernacular form of social capital, and the fact that solicitor's firms (as opposed to barrister chambers) dominate ICA has not hurt them. In Dezalay and Garth's account, local elites built and shaped a new version of ICA. The data, however, show that it was transnational elites of a particular sort-the secant marginals-who were more influential.

\section{Conclusion}

In this article, I have focused on the impact of a relatively stable group of individuals on the development of ICA as an autonomous legal order at the global level. The article casts serious doubt on some of the core claims of Dezalay and Garth, who proposed an alternative reading of the evolution of ICA and, more generally, of the dynamics of legal globalization. Most importantly, they claimed that ICA underwent a transformation in the $1980 \mathrm{~s} / 1990 \mathrm{~s}$, as a result of a struggle between two groups, the

87 See “Queen's Counsel Statistics from 1995 to present.” Available at: http:/www. qcappointments.org/completed-competitions/ (accessed 15 December 2016). The remaining 98.2 percent are all barristers.

88 Toby Landau and VV Veeder.

89 Judith Gill, Stephen Jagusch, Audley Sheppard, Constantine Partasides. 
members of which represented a different legal tradition that demanded different skills and sources of legitimacy. In contrast, the data show that the reconstruction of ICA dates to an earlier time period, when the field became dominated by "secant marginals." This group did not seek to enhance or exploit competition between national approaches; rather, they actively worked to build bridges across legal systems and professions. They did so through "institutional bricolage," combining basic features of various national systems into a new transnational order. Dezalay and Garth were right to notice that the transformation of ICA accelerated in the 1980s and 1990s, as larger numbers of high-stakes cases flowed into the system. But the group on which they focus actually built onto foundations laid much earlier by the "secant marginals."

My analysis shows that the "field settlement" that did occur resulted in hybridization, not the pyrrhic victory of one group over the other(s). None of the individuals working in the foundational period—roughly 1950-1970—was a professional arbitrator; instead, they belonged to a great diversity of professions, with the predominance of attorneys (Figure 1). They operated at the intersection of different legal systems and professions, as skilled "secant marginals" and pioneers of transnational law. As with Nietzsche's tightrope walker, "secant marginals" maintained a fragile balance on the narrow path to transnationalism, stretched between several "towers" of legitimacy.

By the end of the 1960s, stable features of a new, transnational legal profession had emerged at the intersection of various strands of emerging practices and sources of legitimacy, a dynamic reinforced by the practice of re-appointments (Figure 3 ). The current ICA elite (Table 2) reproduced and crystallized the features of the "secant marginals" into a stable professional identity. Members of this elite share common characteristics: they maintain close ties with the business world, through their affiliations to the bar and their connections with arbitral institutions (Table 3); and they accrete intellectual authority within the academic world. Professors become attorneys, attorneys become professors, with each group complementing (and reinforcing) what is, in effect, a hybrid legitimacy. Unlike the "secant marginals," however, this group appears to have been more self-consciously devoted to leveraging social capital (notably education) to accrete global legitimacy. This is a major difference from the "secant marginals," who happened to combine various sociological features resulting from personal trajectories and tastes, rather than choice. Some of the young technocrats are even able to capitalize on their transnational status, in order to build social capital in local arenas (Table 4). 
At a more general level, this article presents a narrative of globalization wherein individuals acting at the junction of various social systems are able to create and then maintain a new transnational space. In ICA, this space has acquired density over time, with newcomers reproducing the perceived features of the pioneers of global law to become its new leaders. This article, of course, does not exhaust the sociolegal analysis of legal globalization, a complex process in which various actors interact in myriad ways. But it does tell a story in which transnational law initially draws strength from its own perceived weaknesses, namely unrootedness and marginality.

\section{References}

Axelrod, Robert (1990) The Evolution of Co-Operation. London: Penguin Books.

Bhatia, Vijay K. (2010) "Accessibility of Discoursal Data in Critical Genre Analysis: International Commercial Arbitration Practice," 10 Linguagem em (Dis)curso 46583.

(2011) "Interdiscursive Colonisation of Arbitration Practice," 30 World Englishes $76-80$.

Bhatia, Vijay K., Christopher N. Candlin, \& Maurizio Gotti, eds. (2012) Discourse and Practice in International Commercial Arbitration: Issues, Challenges and Prospects. Farnham: Ashgate.

Beechey, John (1997) "Book Review of Dealing in Virtue," 24 J. of Law \& Society 569-73. Bourdieu, Pierre (1984) Homo Academicus. Paris: Editions de Minuit.

\footnotetext{
— (1986) "La Force du Droit—Eléments Pour une Sociologie du Champ Juridique," 64 Actes de la Recherche en Sciences Sociales 3-19.
_ (1991) "On the Possibility of a Field of World Sociology," in Bourdieu P. \& J. S. Coleman, eds., Social Theory for a Changing Society. Boulder: Westview Press.

_ (2012) Sur l'Etat_Cours au Collège de France 1989-1992. Paris: Seuil.
}

Bourdieu, Pierre (with Loï J.D. Wacquand) (1992) Réponses-Pour une Anthropologie Réflexive. Paris: Seuil.

Buchanan, Ruth (1997) "Constructing Virtual Justice in the Global Arena," 31 Law E Society Rev. 363-76.

Caron, David D., et al. eds. (2015) Practising Virtue—Inside International Arbitration. Oxford: Oxford Univ. Press.

Carruthers, Bruce G. \& Terence C. Halliday (2006) "Negotiating Globalization: Global Scripts and Intermediation in the Construction of Asian Insolvency Regimes," 31 Law \& Social Inquiry 521-84.

Crozier, Michel \& Erhard Friedberg (1977) L'acteur et le Système_Les Contraintes de L'action Collective. Paris: Seuil.

Dezalay, Yves (1992) Marchands de Droit_La Restructuration de Lordre Juridique International par les Multinationales du Droit. Paris: Fayard.

Dezalay, Yves \& Bryant G. Garth (1995) "Merchants of Law as Moral Entrepreneurs: Constructing International Justice from the Competition for Transnational Business Disputes," 29 Law \& Society Rev. 27-64.

_ (1996) Dealing in Virtue - International Commercial Arbitration and the Construction of a Transnational Legal Order. Chicago: The Univ. of Chicago Press.

Dezalay, Yves \& Bryant G. Garth (forthcoming) "Constructing a Transatlantic Marketplace of Disputes on the Symbolic Foundations of International Justice," in 
Mallard, G., et al., eds., Contracting beyond Boundaries: Private Regulation of International Trade and Finance in the Twentieth Century. Cambridge: Cambridge Univ. Press.

Dezalay, Yves, Didier Bigo, \& Antonin Cohen (2015) "Enquêter sur L'internationalisation des Noblesses d'Etat. Retour Réflexif sur des Stratégies de Double Jeu," 98 Cultures Et Conflits 15-52.

Dezalay, Yves \& Mikael Rask Madsen (2012) "The Force of Law and Lawyers: Pierre Bourdieu and the Reflexive Sociology of Law," 8 Annual Rev. of Law and Social Science 433-52.

Dixit, Avinash K. (2004) Lawlessness and Economics-Alternative Modes of Governance. Princeton: Princeton Univ. Press.

Fligstein, Neil \& Doug McAdam (2012) A Theory of Fields. New York: Oxford Univ. Press.

Franck, Susan D. (2006) "The Role of International Arbitrators," 12 ILSA J. of International and Comparative Law 499-521.

Goldman, Berthold (1964) "Frontières du Droit et Lex Mercatoria," 9 Archives de Philosophie du Droit 177-92.

Grisel, Florian, et al. (2016) "Aux Origines de L'arbitrage Commercial Contemporain: L'émergence de L'arbitrage CCI," 2 Revue de L'arbitrage 403-44.

Hagan, John, Ron Levi, \& Gabrielle Ferrales (2006) "Swaying the Hand of Justice: The Internal and External Dynamics of Regime Change at the International Criminal Tribunal for the Former Yugoslavia," 31 Law E Social Inquiry 585-616.

Halliday, Terence C. (2012) "Architects of the State: International Financial Institutions and the Reconstruction of States in East Asia," 37 Law E Social Inquiry 265-96.

Helmer, Elena V. (2003) "International Commercial Arbitration: Americanized, 'Civilized,' or Harmonized?," 19 Ohio State J. on Dispute Resolution 35-67.

International Chamber of Commerce (1935) International Commercial Arbitration-Practical Hints. Paris: Lecram-Servant.

Jemielnak, Joanna (forthcoming) "Comparative Analysis as an Autonomization Strategy in International Commercial Arbitration," International J. for the Semiotics of Law

Jessup, Philip C. (1956) Transnational Law. New Haven: Yale Univ. Press.

Karton, Joshua (2013) The Culture of International Arbitration and the Evolution of Contract Law. Oxford: Oxford Univ. Press.

Kauppi, Niilo \& Mikael Rask Madsen, eds. (2013) Transnational Power Elites-The New Professionals of Governance, Law and Security. London, UK: Routledge.

Lagergren, Gunnar \& George H. Aldrich (2002) "An Old Judge Remembers," 14 Leiden J. of International Law 307-22.

Legrand, Pierre (2006) "On the Singularity of Law," 47 Harvard International Law J. 518-30.

Lenoir, Rémi (2004a) Espace Social et Classes Sociales," in Pinto, L., et al., eds., Pierre Bourdieu, Sociologue. Paris: Fayard.

(2004b) Du Droit au Champ Juridique," in Pinto, L., et al., eds., Pierre Bourdieu, Sociologue. Paris: Fayard.

Lévi-Strauss, Claude (1962) La Pensée Sauvage. Paris: Plon.

Merry, Sally Engle (2006) Human Rights and Gender Violence: Translating International Law into Local Justice. Chicago: Univ. of Chicago Press.

Munger, Frank (2012) "Globalization through the Lens of Palace Wars: What Elite Lawyers' Careers Can and Cannot Tell Us about Globalization of Law," 37 Law E Social Inquiry 476-99.

Pinto, Louis (2002) Pierre Bourdieu et la Théorie du Monde Social. Paris: Albin Michel.

Puig, Sergio (2014) "Social Capital in the Arbitration Market," 25 The European J. of International Law 387-424.

Sacriste, Guillaume \& Antoine Vauchez (2007) "The Force of International Law: Lawyers' Diplomacy on the International Scene in the 1920s," 32 Law E Social Inquiry 83-107.

Schultz, Thomas \& Robert Kovacs (2012) "The Rise of a Third Generation of Arbitrators? Fifteen Years after Dezalay and Garth," 28 Arbitration International 161-71. 
Schwartz, Eric A. (1997) "Book review of Dealing in Virtue," 12 ICSID Rev. - Foreign Investment Law J. 229-35.

Stone Sweet, Alec \& Florian Grisel (2017) The Evolution of International Arbitration. Oxford: Oxford Univ. Press.

Shaffer, Gregory, James Nedumpara, \& Aseema Sinha (2015) "State Transformation and the Role of Lawyers: The WTO, India, and Transnational Legal Ordering," 49 Law E Society Rev. 595-629.

Tarrius, Alain (2008) "Migration by the Poor and Economic Globalization: Transnational Migratory Flows in Southern Europe," in Gabriel, C., et al., eds., Governing International Labour Migration-Current Issues, Challenges and Dilemmas. London: Routledge.

Florian Grisel Florian Grisel is a Research Fellow at the Centre national de la recherche scientifique and a Senior Lecturer in Transnational Law at King's College London. His research focuses on the emergence and evolution of judicial governance. His doctoral work on international arbitration received the Alexandre Varenne Prize for the Best Dissertation in Legal Theory, and his last book (The Evolution of International Arbitration - Judicialization, Governance, Legitimacy, co-written with Alec Stone Sweet) was published by Oxford University Press in 2017. 